\title{
A tale of three transitions: a year in the life of electricity system transformation narratives in the Irish media
}

\author{
Gerard Mullally ${ }^{1 *}$ and Edmond Byrne ${ }^{2}$
}

\begin{abstract}
Background: This paper focuses on discourses of transition in the electricity system in the Irish print media, with particular attention to both the framing and the scalar referents of the debate. We characterise some of the key contextual drivers for system transformation and suggest that too sharp a distinction between existing electricity infrastructure and systems of the future forecloses the possibility of social learning. Our central question research question is: What lessons can emergent techno-optimistic solutions to electricity system transitions learn from contemporary infrastructure controversies? Using a reconstruction based on print media coverage over a 12-month period in Ireland, we present three contrasting short stories to suggest that there are some commonalities that might provide cues and clues for promoting solutions for transitions to a low-carbon economy and society.

Methods: We divide our methods section into a discussion of theory and methods. In the theory part, we explore the literatures on sustainable electricity transitions, critical infrastructures and social acceptability of energy solutions. In the methods part, we begin from the assertion that storylines help constitute reality allowing constellations of actors to coalesce around certain narratives. We outline the methodological approach to the reconstruction of mediated narratives based on three short stories of electricity system transformations in Ireland.

Results: The three short stories recounted here, the future is smart; blurred lines; and policy versus place, show how narratives of economic recovery and economic growth risk occlude sustainable electricity system transition narratives, generating conflict rather than consensus on the decarbonisation of the Irish economy and society.

Conclusions: Although the public discourse on smart grid technologies is very much in its infancy in Ireland, its rhetorical framing is very similar to that in both the wind farm and infrastructure controversies. The lack of attention to issues of scale, ownership, rhetorical framing and the perceived distribution and fairness of costs and benefits in these controversies could become equally problematic in the roll of smart grid strategies. Smarter green transitions in regions and cities do not depend on technological innovation alone but require social and institutional innovation to ensure constructive public engagement in sustainable electricity system transitions.
\end{abstract}

Keywords: Critical infrastructure, Networks, Reflexivity, Sustainable electricity system transitions, Media narratives

\footnotetext{
* Correspondence: g.mullally@ucc.ie

${ }^{1}$ Energy, Climate and Community Response Group/Sustainability in Society,

Department of Sociology, School of Sociology and Philosophy, University

College Cork, Western Road, Cork, Republic of Ireland

Full list of author information is available at the end of the article
}

\section{记 Springer}

(c) 2016 Mullally and Byrne. Open Access This article is distributed under the terms of the Creative Commons Attribution 4.0 International License (http://creativecommons.org/licenses/by/4.0/), which permits unrestricted use, distribution, and reproduction in any medium, provided you give appropriate credit to the original author(s) and the source, provide a link to the Creative Commons license, and indicate if changes were made. 


\section{Background Introduction}

On April 15, 2014, as the cabinet of the Irish government met to consider the Climate Action and Low Carbon Development Bill, thousands marched on Leinster House the seat of the Irish parliament to protest against wind farms, pylons and transmission cables. Exactly how many thousand is, of course, disputed. The state broadcaster estimated RTE around 2000; the organisers claimed it was closer to 4000; nevertheless, it led to the conclusion that "Irish energy policy is under scrutiny like never before" [1]. These developments were preceded 2 days earlier by three separate but connected events: the announcement by the United Nations Intergovernmental Panel on Climate Change that a largescale transformation from energy based on fossil fuels to renewables was urgently required to contain global warming to $2{ }^{\circ} \mathrm{C}$; the announcement of the shelving of a major wind farm development in the midlands of Ireland consisting of 1000 wind turbines generating $3 \mathrm{GW}$ of energy exported directly to the UK grid; and newspaper coverage of a "monster rally" planned for April 15, 2014, opposing electricity infrastructure development estimated to draw 10,000 protestors on to the streets of the capital. Journalist Harry Magee noted that the opposition to wind farms in rural Ireland was "enough to pre-

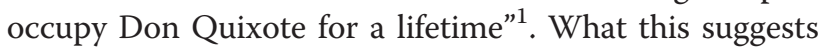
is the Irish electricity system has become the subject of increased societal attention and, in the process, has become intensely political. In Ireland, electricity accounts for less than one fifth (19\%) of energy consumption [2]. Nevertheless, electricity is expected to play a significant role in the transition to a carbon neutral society. If the electricity system can be decarbonised, it could provide the opportunity for low-carbon energy for transport and heating. EU policy documents describe smart energy infrastructure as central for addressing the societal challenge of transitioning to an energy-efficient low-carbon economy [3]. Amin defines smart grids as "a concept and range of functionalities", "designed to be inherently flexible, accommodating a variety of production sources and adapting to and incorporating new technologies as they are developed" [4]. Visions of a future smart electricity grid hold the promise of addressing many of the current challenges in energy production and distribution entailing a physical, technological and social reconfiguration of the system [3]. Smart electricity grids are often presented as offering as a set of tools to optimise the electricity grid and help mitigate climate change, while re-imagining the production of electricity with microgeneration at the level of the household playing an increasing role in the electricity system [5]. In this sense, smart electricity grids can be located within the larger narrative of a transition towards a more sustainable electricity system using an increasingly diverse range of low-carbon technologies to achieve "minimal environmental destruction, maximum social equity, and economic efficiency" [6].

In a study by the Joint Research Centre (JRC) of the European Commission, the smart grid is conceived of in terms of a paradigm shift where "passive distribution and one way communication and flow between suppliers and consumers is going to be replaced by a new paradigm of active distribution that can dramatically change the role of consumers" [7]. In this transition narrative, the grids of the past that were primarily about production, transmission and distribution are presently being eclipsed by the grid of the immanent future which will fundamentally alter the relationship between the production and consumption of electricity. It also suggests a different model of communication than has hitherto been the case. There remains, however, an unfortunate distinction between "smart" and "dumb" in the discourse which often elides the fact that the electricity grid is in fact a multi-layered infrastructure to which many elements have been added through course of history [5]. Smart grids will be built on top of existing infrastructures and will add to the complexity and heterogeneity of the system. The ubiquity of the term smart grid has meant that "the actual transformation of the electricity system has been somewhat lost in translation" [8]. Adapting Laird [9] we ask: what precisely is it that has the potential for change? Is it simply the replacement of existing fuel technologies within the current system of centralised top-down generation, transmission and distribution? And/or is it the replacement of a large fraction of centralised generation with more widely distributed generation, with correspondingly different implications for society? The orthogonal nature of both of these potential transformations merely adds to the technological, environmental, economic and social complexities that interplay across each of this domain and to the attendant increase in uncertainty in social choices. Wolsink [10] argues that while the deployment of smart grid infrastructure is crucial for further renewables deployment, there is a tendency to continue to neglect social determinants. He points out that smart grid is still only "a buzz word without a precise definition". Consequently, smart grids are open to "interpretative flexibility" [5]. A recent study of cooperation in the global and French smart grid industry suggests that there is very little homogenised understanding of "what" the smart grid is and what it could be in the future [5]. At times, however, the emergent paradigm of a sustainable electricity system facilitated by smart grids is portrayed as inexorable (if not yet real and present). Burch [11] stresses that new technologies are not simply exogenously imposed on a social context but are a part of a web of rules, institutions and practices that shape the likelihood and nature of innovation and diffusion. 


\section{The importance of context}

Boyle [12] and Curtin [13] point out that the publication of the International Energy Agency Smart Grid Roadmap and the European Commission's Communication on a Smart Grid Deployment has placed the concept of the smart grid at the top of the political agenda in Europe. In Ireland, this resonates with the official policy narrative established in the Irish government's "Building Ireland's Smart Economy: A Framework for Sustainable Economic Renewal" 2008 [14], where smart grids are primarily imagined as generating new economic opportunities. The Irish government has emphasised the strategic importance of the transmission network and other energy infrastructures, including renewables, to broader economic and social policy goals [15]. Several recent studies on energy transitions in Ireland [12, 15, 16] have highlighted the importance of socio-political and socio-cultural acceptance in the transformation of the Irish electricity system wherein smart grids are seen as being increasingly relevant.

Ireland is implicated in a number of smart grid projects including the North Atlantic Green Zone (covering the northwest of Ireland, including parts of both Northern Ireland and the Republic) [7] and Green Emotion focused on smart mobility [17]. Several technical and economic studies have also been carried out on different constituent elements of the roll-out of the smart grid in Ireland. These include economic analyses of the immediate deployment of the smart grid [18], consumer awareness of smart grid [19], smart meters [20], microgeneration [21], the role of smart grids in renewable power integration [22] and high wind power integration in the electricity grid [23]. These studies variously emphasise a cost-benefit analysis of smart grid policy [24], diffusion of innovation models based on Rogers [19, 20, 25], the optimal (financial and environmental) regional distribution of hybrid energy systems [21], optimal (technical and economic) integration of grid-connected microgeneration technologies at household level [26] and the technical and market challenges for high wind power integration in the grid [22, 23]. Where societal engagement is considered, it is largely confined to consumer acceptance/awareness and education $[19,24]$.

Curtin [13], in a comprehensive overview of a sustainable electricity system in Ireland, calls for a new narrative around decarbonisation built upon the deployment of a smart grid, retrofit of buildings, electrification of transport, increasing penetration of wind into the energy system, and developing the grid to facilitate the connection and connecting Ireland's grid more fully with the Northern European Grid. Any new narrative, however, will have to contend with, and perhaps contest, existing narratives in the Irish context.

\section{Our approach}

Our contribution to the workshop Smart Energy System Transition in Cities and Regions and in this special edition is slightly different. Our focus here is less on the techno-economic and policy dimensions of smart grids than on the cultural opportunities for locating them in public (specifically mediated) discourses on sustainable electricity in Ireland. This is quite challenging given that existing visions of future smart grids per se are relatively uncontested when compared with, for example, the grassroots mobilisation in other countries against smart meters [3]. Nevertheless, following Skjølsvold et al., we suggest that too sharp a distinction between so-called dumb and smart grids is problematic.

For all of the allusion to the virtual contained in the imagery of the smart grid (e.g. [27]), its social embedding depends on the development of new material infrastructure that has the potential to divide as well as connect. Any discussion of a sustainable electricity system that seeks to exclude the challenges already encountered in the development of the necessary infrastructure for the grids of the future (e.g. generation, transmission and distribution) could further render the physical and material dimensions of electricity systems "invisible" [5, 28, 29] and occlude potential lessons to be learnt about sociocultural barriers to deployment.

What is equally challenging is the ambiguous status of regions in Ireland "with their increasing fluidity across ceaselessly shifting boundaries" [30]. Rather than providing a fixed geographical point of reference or cultural identity marker, regions in Ireland are a flexible construct performing multiple, often overlapping, environmental (e.g. water and waste management), economic, political and administrative (e.g. EU and local government) functions. Regions in Ireland are open to quite permissive interpretations. For example, the Republic of Ireland can plausibly be interpreted as a region within the EU [31], which in turn can be interpreted as a region in the wider global context [32]. In the context of the constitutional settlement with regard to Northern Ireland, the Republic of Ireland can be regarded as a region in the context of the so-called British Isles [33]. Regions can similarly be interpreted to indicate the subnational level, to distinguish between Dublin as the capital city and locus of central government and the rest of the country, or alternatively between the urban and the rural [34]. Lennon and Scott [35] suggest that while energy systems often remain hidden or unobserved in an urban context, rural communities experience the consequences of a shift to low-carbon technologies more directly as biofuels, solar energy and wind energy, and associated electricity infrastructure (e.g. mega-pylon projects) change the appearance and function of rural places. Abstract or invisible systems are often rendered "visible" in times of controversy and conflict. 
Accordingly, we have approached the subject matter by focusing on discourses of sustainable electricity in the Irish print media, with particular attention to both the framing and the scalar referents of the debate. We begin by considering some of the theoretical literature on energy (specifically electricity systems) transitions, critical infrastructures and social acceptability. Our central question research question is What lessons can emergent techno-optimistic solutions to electricity system transitions learn from contemporary infrastructure controversies? Using a reconstruction based on print media coverage over a 12-month period in Ireland, we present three contrasting short stories: (1) a declaratory discourse on elements of the smart grid that is uncontroversial but is heretofore confined to a narrow national discourse coalition; (2) a private sector discourse on electricity for export centred on the midlands region of Ireland that generated substantial oppositional civil society mobilisation but was ultimately abandoned due to a shift in energy policy in the UK; and (3) a public sector discourse on upgrading the electricity grid as a prerequisite for an electricity system transition to a lowcarbon economy and society that was greeted with the highest level of objection in the history of the Irish state. Despite the contrasting features of these cases, we suggest that there are some commonalities that might provide cues and clues for promoting solutions for transitions to a low-carbon economy and society.

\section{Methods}

\section{Theory and method}

Theory: sustainable electricity transitions, critical infrastructures and social acceptability

Specific constellations and conditions of power, paradigms (knowledge) and conflict intersect to create or prevent a transition/transformation of the social order [36]. The energy system has been characterised as a complex adaptive societal system comprised of all of the actors and artefacts that together produce the societal function energy [37]. The opening line of an Irish government policy statement puts it far less prosaically stating that "energy is the lifeblood of Ireland's economy and society" [38]. Lennon and Scott [35] point out that although energy systems and social systems are often highly interconnected, "the forms in which societies are energised are often hidden from direct observation, especially in the case of more distant forms of energy" in an era of interconnected smart grid spanning continents. At the technological level alone, the extent of interconnectedness is immense: "electric power grids are among the most complex networks ever made" [4]. The traditional centralised system where electricity flows from large power plants through the transmission and distribution networks to (passive) consumers is characterised by a high degree of inertia [39]. The resilience of energy systems requires adaptability, as well as "the dynamic interplay between infrastructures and social structures". A balanced mixture of centralised/decentralised energy production tends to make for more "robust systems and more reliable energy security" [40].

Negotiating the transition from a fossil fuel-based, mostly centralised, system to one that is more renewable based, diverse and more decentralised is a significant challenge [41]. An energy transition is a complex process that involves "co-evolving markets, networks, institutions, technologies, policies, individual behaviour and autonomous trends" [37]. Energy transitions involving the shift from one regime to another are conceptualised in the transition literature as occurring when landscape pressures destabilise prevailing regimes, providing breakthrough opportunities for promising niches [37]. The energy sector is therefore "a strategic action field: between stability and transformation" [42]. Carley and Andrews locate this within a "sustainability electricity scale spectrum": composed of a combination of conventional macrogeneration facilities, increased integration of micro-grid systems, distributed generation, microgeneration units and end-user efficiency. For example, a policy structure which puts a large emphasis on micro-grids could enable citizens to "become much more participatory in their energy provision" [6]. This, critically, also has the capacity to foster behavioural change at the demand side, leading to potential for significant change in terms of both overall large-scale generation demand and carbon emissions associated with energy provision. This contrasts directly with the outcomes associated with either the maintenance of a traditional topdown "big transmission and distribution" model or the development of a market-driven top-down "energy services companies" model, which promote a "high level of passivity from consumers" and actually result in increased projected overall demand and poorer reductions in carbon emissions [43]. In short, such models are structurally problematic as they tend to promote the continuation of unsustainable, innovation-led consumptive growth. Visions of future electricity systems in Europe vary considerably in scope and scale, but while "currently political considerations and economies of scale seem to favour large solutions, the emphasis in smart grid discussions also focuses on local and regional solutions for the challenges electricity grids are facing" [39].

Van der Vleuten et al. identify a common view of infrastructure as: "technologies of connection that play a constitutive and integrative role in economies and societies". Related terms, such as "networks" or "large technical systems", convey understandings of connectivity and "an integrative foundation for modern societies" [44]. They draw our attention to "myth of ever increasing connectivity" in modern society, which they argue 
masks a paradox of connection and rupture since infrastructure can divide as well as connect [44]. Latour [45] draws our attention to the "empty spaces" created by networks. The creation of the requisite infrastructure for an electricity network often assumes that spaces between the networks are empty, a void to be filled by persuading communities of the social necessity of the infrastructure, and that its social cost can be defrayed through compensation and community gain. As the JRC research has found, it is generally the case that the social acceptance of large infrastructure projects is mostly interested in the passive consent for the construction of such projects [7]. Alternatively, the smart grid literature often imagines its publics, the consumers of immanent system configurations as homo economicus to be informed or educated through visualisations of energy consumption via smart meters. This is largely based upon implicit deficit models and assumptions of typical publics that can structure scientific discourse. Our point here is not only to cast aspersions on the necessity of visions but to also highlight the equal importance of reflection. Any niche level innovation (in spite of any claims to being the emergent dominant social model) struggling for ascendance will often try to establish legitimacy by recourse to a discourse of technological innovation-"We have the technology, this time it will be different"! The risk here of course is that it neglects the issue of path dependence and the old adage that those who fail to learn the lessons of history are condemned to repeat its mistakes-when driving towards a destination, it is good practice to occasionally glance at a rear view mirror. Anything less implies an ahistorical, decontextualised approach that already builds in the seeds of societal rejection. As Ballo suggests, the gap between the future imaginaries of a techno-epistemic network and communication to the public seems to be contingent on how these networks imagine publics. Grids, smart or otherwise, are an abstract concept. As academics or practitioners, we can map them and model them; as citizens, our point of connection is often literally "plug in". Our access to the wider systemic reality often only surfaces at the level of contestation and controversy. The social embedding of technological solutions is less dependent on their rationality, but on their social acceptability. That said, controversies provide a window on the contextual conditions that could influence the success and failure factors of potential technological solutions to pressing social problems. Reflexive approaches to societal engagement [12] have begun to attract attention over the last decade or so where an emphasis on the participation of many social groups crossing multiple levels of society has become more commonplace. Technology only achieves societal acceptance when it has the support of experts, policymakers and citizens; people are willing to adopt and use it in their own specific contexts; and they have some say in shaping the technology [10]. Public discontent and social rejection of new infrastructures highlight a key challenge for sustainable technology proliferation: "no matter how brilliant the technology or perfect the scheme" [30], any challenging technology will depend on how it is "built into society" [31]. This indicates a need for an improved understanding of key contextual factors such as scale, ownership, rhetorical framing and the perceived distribution and fairness of costs and benefits' [12].

\section{Methods}

We begin from the proposition following Lennon and Scott (2015) that probing the constitution of alternative futures creates sensitivity to the social complexity of realising low-carbon transitions in economically dominated decision contexts [28]. Equally, we agree with their assertion that storylines help constitute reality allowing constellations of actors to coalesce around certain narratives. The empirical section of the paper is based on the contention that the media plays a key role in the production, transformation and dissemination of knowledge [46]. The research follows a deductive-inductive loop $[47,48]$, beginning with a content analysis of Irish newspapers using the Nexis-Lexis database.

The initial search was based on a content analysis of the data informed by the key structuring aspects of the literature on the social dimensions of smart grids. Key terms like smart grids/electricity grids, smart meters/ electricity meters, electric cars, microgeneration, microgrids, distributed generation, solar power, hydroelectricity, biomass, wind power, sustainable energy and sustainable electricity were used to construct the data set. Given the high-profile coverage of the pylon controversy in Ireland, it was added as a further search term independently. Recognising the agenda-setting function of broadsheets [48], we decided to confine our search to five national newspapers (three daily newspapers and two weekly/Sunday newspapers). Taking the convergent events of mid-April 2014 as our point of departure, we backcast over the previous 12 months to examine the pathways and trajectories of various components of a potential electricity transitions storyline.

The timeframe is, therefore, between April 15, 2013, and April 15, 2014. We chose to filter our search further by confining it to "major mentions" in national broadsheet newspapers. In searching for the various elements that make up the smart grid, several elements do not really feature in Irish media discourse: terms like microgeneration, micro-grids and distributed generation do not appear at all in the timeframe considered, nor indeed does sustainable electricity as a specific phrase. Hydro-energy, wave energy and biomass only appear in the context of 
discussion of wind power and specific energy efficiency measures. While solar energy does appear $(n=51)$, it is large in the context of the investment portfolios of Irish energy companies outside of the Irish context, i.e. internationally, and has been excluded therefore from the sample. The total sample for the study consists of 512 newspaper articles during a 12-month period. If we consider the total coverage over the sample period, $63 \%$ is dominated by coverage of controversies around electricity infrastructure (Fig. 1). The coverage of electricity infrastructure is in turn dominated by two specific controversies: proposals to generate electricity for export from industrial-scale wind farms in the midlands region and proposals to upgrade and extend the electricity grid as part of a large-scale strategic investment in the Irish electricity system cross-cutting different Irish regions.

\section{Results and discussion}

Three short stories: "the future is smart", "blurred lines" and "policy versus place"

\section{The future is smart}

The integration of high levels of wind onto Ireland's small and relatively isolated grid has spurred the deployment of some aspects of the smart grid. There is effectively only one electricity grid and one market on the island of Ireland. There is a single owner of the networks on the island of Ireland (ESB Networks [incorporating NIE]): “ESB

Networks operates the part of the grid known as the distribution system...this is the part of the grid network in which significant infrastructural investment is required to facilitate the emergence of a smart grid" [13]. There is also a single transmission system operator (EirGrid plc. (incorporating EirGrid and Systems Operator Northern Ireland)). This means a limited number of parties are involved in promoting a particular strategic direction. Stakeholder engagement has been driven by Smart Grid Ireland, which is an industry-led network of organisations based in, or operating out of, Northern Ireland and the Republic of Ireland-seeking to jointly exploit new commercial opportunities in the smart grid sector, locally, nationally and internationally. Member organisations are drawn from industry, research bodies, universities and government agencies. The Sustainable Energy Authority of Ireland (SEAI) has also taken a leading role in coordinating the voice of various stakeholders by convening a group aimed at the development of a roadmap for the deployment of the smart grid to 2050: Many of the elements of the smart grid associated with the transmission system are already in place, arising from the high levels of wind penetration.

If we turn to the media coverage of the smart grid discourse, what we can see traversing categories like sustainable energy, smart grid, electric cars and energy efficiency is the emergence of a "discourse coalition" [49] taking shape around niche level innovations for components of smart grid technologies and systems that mirror the policy narrative identified above. The narrative is largely sustained in the business and motoring sections of the newspapers. The category of sustainable energy is largely dominated by coverage and publicity for initiatives by the SEAI which emphasise regaining control over our electricity system and energy independence through renewable energy. To illustrate the point, if we removed references to SEAI from our sample, the sustainable energy category would shrink to around $4 \%$ of the sample. The theme of control resurfaces in the energy efficiency category, but in this case, it is focused on giving the customer control through the use of smart meters ${ }^{2}$. While the media discourse on smart grids is certainly in the early stages of development and diffusion, there is something of an inexorable quality about the discourse. An advisor to the ESB's $€ 200$ million Cleantech Fund summarising the opportunities for Irish business captures this very well: "wind is taking off, solar has arrived, smart

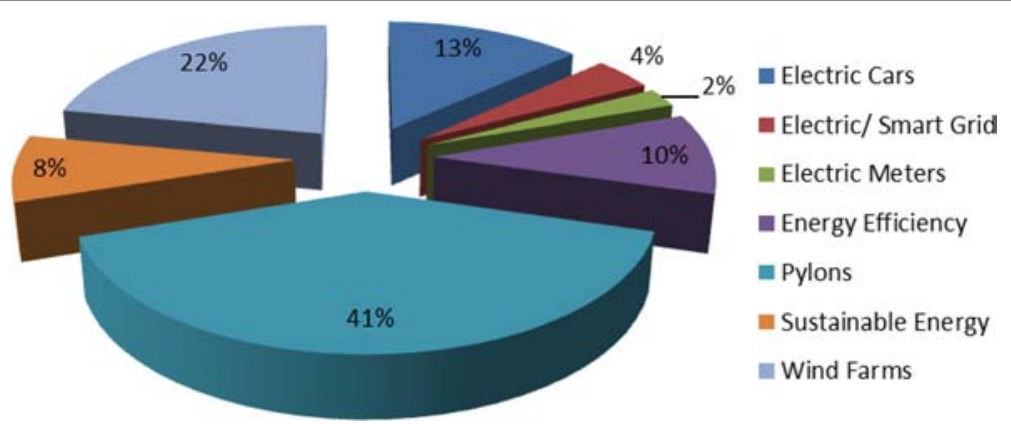

Fig. 1 Total coverage over the sample period 
grid is coming. It's clear there will be changes in the way electricity is generated, transported and consumed...if we can crack smart grid, we will have intellectual property we can export across Europe and the planet" ${ }^{3}$. Certainly, the discourse may well evolve in time to include the potential for social and regional innovation within its narrative, but in this case, the scalar references are national and global.

This story resonates with Ballo's [3] research on Norway that shows that the discourse of the future smart grid is taking place between a network of actors with recognised expertise, competence and knowledge "in the drivers' seat" of a process of comprehensive socio-technical change. Ballo suggests that the visions of these actors are partially conditioned by national, technological and economic imaginations of the future. It may be prudent, however, to occasionally look to both the past and the present to understand how the transformation of the physical, technological and social configuration of the electricity system might potentially be greeted by the public. Beyond the technoeconomic optimism of the prospects for export-led growth lays the contentious nature of physical infrastructure development in Ireland best illustrated by the cases of wind farm development and grid infrastructure development.

2. Blurred lines

The second case has its origins in a memorandum of understanding $(\mathrm{MoU})$ for renewable energy trading between the Irish and UK government in January 2013. According to Lennon and Scott, two privately financed companies Element Power and Mainstream Renewable Power sought to capitalise upon this development with a plan to export all of the energy to the UK from a number of wind farms proposed for the Irish midlands and be directly connected to the UK grid via existing submarine transmission cables[35].

The sample begins by putting the story of Irish wind in context. "It is only 21 years since the first wind farm in Ireland opened for business...there is now 161 wind farms across the country capable of producing $1,755 \mathrm{MW}$ of power...25 large scaleprojects will be connected to the grid by 2020 , and another 74 to the ESB network". "Concern about climate change means that $40 \%$ of all electricity must be produced from renewable sources and most of it is coming from wind". The article points out that the 99 (major wind) projects due to come on stream by 2020 are at an advanced planning stage and have been given dates for connection to the national grid and also that offers to connect additional capacity bring the total up to $4000 \mathrm{MW}$. The most controversial of these involve two plans for large-scale farms in the midlands to serve the UK market. "One is from Mainstream Renewable Power, which plans to build farms producing $5000 \mathrm{MW}$ of power for export to Britain via underground cables. The second is from Element Power, which has struck a deal with the UK's national grid to supply it with wind energy from 40 planned farms".

A conference on wind energy in Co. Offaly cohosted by Mainstream Renewable Power provides a glimpse of the debate in microcosm. The CEO of Mainstream Renewable Power spoke about the need to reassure opponents of wind farms in the midlands if Ireland is to benefit from "a 'once in a generation' chance of capitalising on its wind energy resources". Meanwhile, protestors outside the conference were chanting slogans like "Welcome to the midlands, England's offshore wind farm" ${ }^{\text {" }}$. Wind farms have also been subject to party political contestation as the leader of Fianna Fáil, the main opposition party, has also adopted the storyline that the midlands' proposals were "scaring communities and causing division", claiming "a lack of transparency governing such developments, and no consultation with local communities"7. Meanwhile, the Irish government Minister for Communications, Energy and Natural Resources, Pat Rabbitte, addressing the annual Irish Wind Energy Association conference in October, argued that concerns about wind farms in the midlands had been "needlessly stoked by unthinking communication by some developers" ${ }^{\prime \prime}$.

A second wind farm story that stands in direct contrast to the wind for export narrative of the midlands controversy was also present in our media sample. The Minister for Communications, Energy and Natural Resources used the occasion of the official opening of the first Irish community developed wind farm in Templederry, Co. Tipperary, to stress the need for consultation on a national planning policy for renewable energy export. He also drew a distinction between the "community initiative which produces energy for domestic consumption and the separate question of developing renewable energy for export". It is worth reflecting on the official press release as it provides us with an insight into the systems thinking structuring electricity policy:

While the debate continues over how best to tackle rising energy costs, insecurity of supply, and the obvious downsides of a carbon driven energy sector, it 
has become increasingly apparent that what is needed is a broad mix of both top-down and bottom-up initiatives. The Templederry project is, I believe, a template for the future and I fully expect to see many more of these community led projects, where local people seize the initiative in powering Ireland for the 21st Century [49].

At first glance, this seems to be encouraging local communities to "seize the initiative" themselves while recognising a potential framework for distributed generation, but in reality it offers nothing by way of either structural or policy support and appears to explain the equating of community with self-sufficiency as discussed earlier. Perhaps Paul Kenny of Tipperary Energy Agency, closely involved with the Templederry Community Wind Farm Project, provides useful insight on the nature of the fragmentation when he reflects "The bottom line is that the negative lobby has been driven by fear of the very big projects that have very little community input or gain. There was no issue before the big projects came on stream, and what people are attacking is wind energy, but what they should be attacking is corporate dominance over our energy supplies" [50].

In 2014, political struggles between the UK government and the European Commission on binding targets for renewables in 2030, however, began to overshadow local controversies. By March 2014, it had become apparent that talks had stalled between the British and Irish governments on the export deal to the UK; consequently, the midlands developments appeared to be under threat. ${ }^{9}$ The Minister for Communications, Energy and Natural Resources argued that despite the shelving of the project that "in the context of the internal market and greater integration, greater trade in energy between Britain and Ireland is inevitable in the post 2020 scenario" $^{\prime 10}$.

Members of one of the opposition groups in the Meath/Westmeath area argued that they were not anti-wind and fully understood the need for renewables, but "the Department of the Environment and the Department of Energy had not engaged with communities on the issues"11. The Irish Times, characterised the 5th IPCC report on climate change as a "wake-up call on energy": "whether or not a wind energy export opportunity materialises in the future may be in the lap of the gods following the collapse of a proposed agreement with the British government, but there can be no doubt that wind and other forms of renewable energy will be elements of a global transition to a low carbon economy no longer reliant on fossil fuels - and very heavily so in Ireland's case". ${ }^{12}$ The National Economic and Social Council noting a shift from broad social support for wind energy growth and of electricity infrastructure to a "more critical mood" published Wind Energy in Ireland: Building Community Engagement and Social Support in July 2014 to examine best practice in Ireland and internationally [51].

The case in the midlands region shares certain common features with the previous narrative in that there is a somewhat inexorable quality about the framing of the issue by both the developers and the Irish government. At one level, this sustained a discourse coalition around the energy for export narrative and that the opposition cannot stand in the way of the future. Where the storylines become blurred is along the public/private, internal (Republic of Ireland)/external (UK), and opportunity/threat axes. Certainly, to begin with, there was a shared narrative of national interest and future economic development possibilities among the developers and policymakers. Ultimately, the narrative of "national interest" and "community gain" was successfully countered, by a narrative of post-colonialism and external threat. The dominant narrative of economic renewal was undercut by more traditional narratives where the national interest was in direct opposition to more traditional constructions of community.

Returning to our framework, issues of scale, ownership, rhetorical framing and the perceived distribution and fairness of costs and benefits saw the "national interest" subsumed within historical post-colonial narratives. Any discussion of local or community contributions to electricity system transitions was effectively crowded out by the controversy surrounding the industrial scale of midlands proposals. Equally, any notion of community gain was eclipsed by a perception of private gain. The fact that none of the electricity produced would feed into the Irish electricity system also broke any connection with the broader debate on addressing climate change in Ireland. What it did feed into was a very potent historical narrative around the perceived distribution and fairness of the cost and benefits wherein the UK would benefit and the cost would ultimately fall on Irish communities. The government, opposition parties and the opposition to the development did converge around one point, namely that the form of communication by the developers with communities was partially to blame in creating the controversy. The successful reframing of the issue by oppositional groups meant that 
the factually disconnected issues of the proposals in the midlands and the upgrading of the national grid became rhetorically conflated. The issue in the midlands became the "cause célèbre" for regional opposition to infrastructural dimensions of electricity system transitions in Ireland.

3. Policy versus place

In 2008, EirGrid, Ireland's transmission system operator, embarked on an investment programme known as Grid 25-A Strategy for the Development of Ireland's Electricity Grid for a Sustainable and Competitive Future. In July 2010, the Department of Communications, Energy and Natural Resources published Government Policy Statement on the Strategic Importance of Transmission and Other Energy Infrastructure. Both documents highlighted the strategic importance of the electricity network for the twenty-first century.

Our ability to rebuild the economy, deliver regional development, create jobs and growth and ensure the wellbeing of everyone as well as realising the economic potential of Ireland's own renewable energy resources requires significant energy infrastructure. And starting now, over the coming years, Ireland needs to deliver a world class electricity transmission system in all the regions which meets the needs of Ireland in the $21^{\text {st }}$ Century. [38]

Grid 25 proposals come under the ambit of the fast-track planning processes under the Strategic Infrastructure Act introduced in 2006 to "secure speedier delivery of key infrastructure through providing a one-step consent procedure, rather than the conventional development control process" [28]. Several recent studies on energy transitions in Ireland $[14,51,52]$ have, however, increasingly highlighted the importance of socio-political acceptance in the transformation of the Irish electricity system. Research linking best practice on social engagement internationally and the Irish context has been reviewed by NESC [51]. In 2013, the Green European Foundation (GEF) published "Sustainable Democratic Energy for Ireland and Europe: A case for renewables and participation" [12]. Accordingly, both EirGrid and the Irish government were explicit on the need for public acceptability, and EirGrid developed its public consultation roadmap-Project Development and Consultation Roadmap [53]. Two of the Irish studies $[12,14]$ published prior to the controversy characterise the process in the EirGrid, Grid 25 projects as a step change in community consultation in Ireland. Nevertheless, from 2013 onwards proposals to develop and modernise the electricity grid have also mobilised significant opposition, specifically the construction of $400-\mathrm{kV}$ overhead lines and associated pylons across rural regions: from Munster to Leinster ("Grid Link"), across Connaught ("Grid West") and cross-border between the Republic of Ireland and Northern Ireland from Leinster to Ulster ("North-South Interconnector"). Rather than a step change in community consultation, the proposals led to one of the largest community mobilisations since the Irish anti-nuclear movements in the 1970s [53] and the receipt of 35,000 submissions related to grid infrastructure in January 2014.

National opposition to pylons only gathered momentum in earnest from October 2013 onwards but spread very quickly. In October, an article in the Sunday Independent pointed out that "a people's revolt against a controversial (EURO) 3.2bn power project that will dot 4,000 new high voltage pylons over much of rural Ireland is gathering momentum with dozens of towns and villages across the country banding together to fight the plan"13. From the outset, the aim of the opposition groups centred on the undergrounding of the grid upgrades. EirGrid's planned upgrades are supported by business lobby group Chambers Ireland as "vital for business" ${ }^{\prime 14}$. Grid Link is one of three elements of EirGrid's Grid 25 plan to upgrade and reinforce the national grid by 2025. A second is the NorthSouth Interconnector which has been opposed in Meath, Monahan and Cavan, and Grid West has proved to be less controversial. In November 2013, groups opposed to the new Grid Link plan to connect Leinster and Munster began to link with the North East Pylon Pressure Group, when a group of 1000 people gathered at a public meeting to galvanise opposition nationally, and an estimated 1500 people hiked through the Comeragh Mountains in Co. Waterford in protest against Grid Link. In late November, the Minister for Agriculture, Food and the Marine became embroiled in the controversy at the annual general meeting of the Irish Creamery and Milk Suppliers Association (ICMSA) in Co. Limerick. The president of the ICMSA reflected what he saw as the view in rural Ireland: "there is a very real sense that as far as Eirgrid - and, to a lesser extent, the state - is concerned, that the matter has been settled and that us poor culchies [derogatory term for rural dwellers] are just going to have to deal with a decision that is already made"15. Given the scale of the reaction in rural communities and the political fallout within the Energy Minister's own (labour) party, the deadline for public consultation on the proposals was extended until 
January 7, 2014. In December, a Sunday Independent poll of TDs (MPs) and Senators on the Oireachtas (Parliament) Communication Committee wanted the project to go underground. A recurrent theme in the newspaper coverage is that "there is a sense that lip service is being paid to communities, and they are not being listened to" ${ }^{\prime 16}$.

As the consultation period drew to a close in early January 2014, the Minister for Communications, Energy and Natural Resources conceded that "consultation between national authorities and communities concerned over the erection of pylons had not been good enough"17. The Minister for Jobs, Enterprise and Innovation weighed in arguing that the infrastructure was necessary for regional development: "the criticism I would get from political colleagues is that there isn't a spread on employment growth, that it's becoming too urban centric, too Dublin centric. Clearly, if we want to have the regional spread we have to be able to offer the infrastructures - robust infrastructure -across the country"18. After the submission deadline, it emerged that 35,000 people had contacted EirGrid as part of the consultation process. A particularly acerbic article in the Irish Independent noted that "electricity may be the physical energy at the heart of this controversy but, make no mistake, the real driving force here is trust - or the lack of it...The switch has been thrown. The game is on. A row about safety standards and electrical pylons has become something closer to a debate about truth and power" ${ }^{\prime 19}$.

The ongoing organisation of anti-pylon protestors and the threat to target the local election continued throughout January with the announcement by the Pylon Alternative Alliance that groups from around the country have been meeting since December with a view to targeting the local elections. The group has modelled itself loosely on the structure of the Gaelic Athletic Association (a national sporting and cultural association with independent parish and community groups linking into a county and central committee).

In January 28, the Minister for Communications, Energy and Natural Resources announced the formation of an independent panel headed by a former high court judge to fully review the undergrounding of cables. The independent panel will "help assess the options of running the cables underground or overground. It will advise Eirgrid on the terms of reference for the studies ...the two studies would take account of the environmental, technical and cost factors. Studies will also take account of the impacts on tourism and equine health. And an updated report on the health impact of high voltage lines will also be commissioned" ${ }^{20}$. At the same time, EirGrid announced details of compensation packages for landowners and funds for effected communities. However, the Pylon Alternative Alliance characterised the compensation package as premature. Reflecting on the pylon controversy, the CEO of EirGrid conceded that the "national grid operator obviously did not do a good job explaining to communities that the power lines would not be used to export help export power from large-scale wind farms proposed for the midland"21. He highlighted the need for broader social acceptance rooted in clear procedures, which is world presenting at length:

I think we need to come to a view, as a society, what is the process we go through, (where) the public knows, and communities know, this is where I can engage, this is how I can influence, and this is what's going to happen. And developers similarly know these are the stages that it's going to go through. I think we need to get to a point where there's a process that's accepted by society in its widest possible context.

The case for undergrounding was challenged by a statement made by the Commissioner for Energy Regulation stating that "end-users would be hit by a hike of at least $3 \%$ in their annual bills"22. By March 2014, a poll by the Sunday Independent/ Millward Brown found that 70 \% of voters "want the state to abandon controversial plans to erect giant pylons across the countryside and instead put the project underground" ${ }^{\prime 2}$.

In April, the Minister for Communications, Energy and Natural Resources announced that his department, along with the Department of the Environment, and the National Economic and Social Council were now looking at "best practice in other countries in the area of social acceptance and community engagement in infrastructure projects" 24 . Perhaps a fitting postscript to the case was the publication of Green Paper on Energy Policy in May [50] and the identification of possible underground routes for the Grid West project by EirGrid in June 2014. ${ }^{25}$ Referencing the green paper, a commentary in the Irish Times suggests that while it is all very well "to rebrand us all as energy citizens, collectively probing Ireland's pathway towards a low carbon, inclusive competitive and secure energy society" this must be located within "an overall framework of goals and policies to enable citizens to play an active role in achieving this aspiration in the context of 
environmental sustainability" ${ }^{26}$. Reacting to EirGrid's exploration of underground routes for the Grid West project, a commentary in the same newspaper summarised the controversy in a nutshell: "The centralisation of power stifles discourse so that public consultation can be seen as an unwelcome irritant. Distant paternalism frowned on active, informed citizenship and local anger, rather than critical analysis, was the reaction" ${ }^{27}$. One of the outcomes of the controversy was that the discourse coalition built around the narrative of national recovery and regional development came into conflict with a rhetorical framing by communities that pitted a national discourse of low-carbon development against sustainable community, state versus community and urban versus rural. In effect, it created regions of protest. In part, this was created by a paradox in the institutional architecture governing critical infrastructure for large-scale socio-technical systems. The lessons learnt in the midlands controversy are equally applicable to this case. As Lennon and Scott point out, the rescaling of the planning process to the national level for projects falling under the provisions of strategic infrastructure legislation bypass public involvement in statutory procedures at local level and effectively reconceptualise "public interest" as "national interest"[28]. This suggests that there are structural as well as cultural roots to the controversy, where the seeds of discontent are already present in attempts to curtail public involvement in large-scale projects in the national interest [54]. They also point out that these debates set up intractable collisions where the conflict between the global environment (e.g. climate change) and the local environment (e.g. rural land use and health concerns) led to contention, rather than consensus on the direction of a transition to a post-carbon economy and society [35]. Indeed, any connection to narratives relating to energy transitions, climate change or international obligations was overwhelmed by the dominance of economic storyline. The postscript to this story is that a sparked series of measures that suggest that another outcome of the controversy may be that some social learning has taken place. In addition to government actions, e.g. the establishment of the Independent Expert Panel that reported in October 2015, EirGrid undertook a review of its own public consultation procedures in 2014 [55] and launched a draft Grid Development Strategy for consultation in March 2015 [56]. EirGrid has also revisited its plans to develop new infrastructure in the Grid West and Grid Link proposals. In the case of Grid West,
EirGrid promised to explore the potential of undergrounding the infrastructure. More importantly, in the case of Grid Link, they introduced what they have labelled the "Regional Option" [57]. The Regional Option uses a technology known as "series compensation". "This would be the first time it will be deployed on the Irish transmission grid. It is an advanced, smart grid technology that will enable more power to flow through existing lines, and so does not require new $400 \mathrm{kV}$ overhead lines" [57]. The current Minister for Energy Alex White welcomed the Independent Expert Panel's view that the emergence of a third option means that no significant new Grid Link transmission infrastructure, either overhead or underground, will be built in the short to medium term [58]. He also noted that the outcome "demonstrates that meeting citizens' concerns about energy infrastructure can be compatible with taking the necessary steps to decarbonise our energy system and tackle global warming" [58]. In a curious twist in the tale, these controversies may well have accelerated the use of smart grid technologies to advert costly and divisive conflicts on these scales in the future.

\section{Conclusions}

Towards a smarter future electricity system?

The three transition tales reconstructed here may well be particular to the Irish context, but they are entangled in the wider nets of globalisation, climate change and the need for energy transitions in the twenty-first century. The debate around the transformation of the Irish electricity system in Ireland is suffused with a narrative of optimism (technological, economic, policy), nationalism (energy independence, Ireland as a world leader in smart grids) and consumerism (often under a banner of enhanced economic competitiveness and attractiveness to globalised inward investment).

Although the public discourse on smart grid technologies is very much in its infancy in Ireland, its rhetorical framing is very similar to that in both the wind farm and infrastructure controversies. As of yet, based on analysis of the cases presented herein, the space for public discourse on smart energy transitions in regions and cities has not yet emerged. Nevertheless, the emerging policy narrative signals the growing importance of renewable electricity sources, distributed generation and smart technology for the electricity system of the future.

We return to our question: What lessons can emergent techno-optimistic solutions to electricity system transitions learn from contemporary infrastructure controversies? The conflation of generation technologies with 
large network models has facilitated cleavage within groups which might be viewed as having both "conservative" and "progressive" tendencies. For example, business representative organisations and political leadership (across left, right and green) have supported (big) "wind", via a continuation of the top-down mode of network generation and transmission, while farm representative groups and many rural and community groups have expressed opposition or concern over proposed developments. Meanwhile, some environmentalists, trade unionists and green leaders have supported the development of a proposed top-down "big" generation, transmission and distribution model as a means of meeting renewable targets and the development of a European super grid and for the potential to create economic growth and, by extension, jobs. Other environmental activists by contrast oppose the environmental and visual destruction associated with large pylons and wind farms and the lack of any real benefits to, or engagement by, local communities. There has been very little public debate favouring microgeneration, biomass or energy conservation measures as alternatives or supplements to a profit-driven generation and distribution system.

What these controversies show is that a focus on technological and physical infrastructure development that neglects to give due attention to the institutional and social infrastructure on which to build the social acceptability of solutions risks being sent back to the drawing board. The lack of attention to issues of scale, ownership, rhetorical framing and the perceived distribution and fairness of costs and benefits could become equally problematic in the roll of smart grid strategies. While the value of electricity system transitions to the economy is of great importance, it should not mean that consideration of the values underpinning such a largescale social transformation should be ignored. As the wind farm and infrastructure controversies demonstrate, the lines between regional opposition to a specific development and widespread social opposition to key elements of Irish energy policy can be become blurred very easily. These are lessons that need to be learned when attempting to create any new narrative of decarbonisation of the economy and society. For example, recent moves to commercially develop "solar farms" in Ireland need to learn from the experience of wind farms; similarly, plans to roll out smart electricity meters in Ireland may need to learn from the opposition to the introduction of ("dumb") water meters in Ireland and the growing opposition to smart meters in the UK.

The recent introduction of neologisms like "energy citizens" in Irish energy policy discourse is as of yet largely an empty signifier [35], but one that may gain definition through the lessons learned in these controversies-not just about the need for better public engagement but also the need to create institutional opportunities to allow for this engagement to take place. If so, smart technologies may well contribute to the development of smarter, less unsustainable societies.

\section{Endnotes}

1"Events refocus minds on climate change and difficult decisions", Irish Times, April 14, 2014.

"Smart grids will give consumers control", Irish Times, November 21, 2013.

3"Irish clean-tech start-ups attract the attention of International investors", Irish Times, September 23, 2013.

4"EU renewable target is driving industry forward", Irish Independent, April 15, 2013.

5"Concern mounts as plans to build 100 new wind farms take shape”, Irish Independent, April 15, 2013.

6"Wind farm protestors must be reassured of opportunity, forum told", Irish Times, May 1, 2013.

7"Planned turbines put the wind up locals", Irish Times, June 20, 2013.

" "Wind farm fears needlessly stoked by developers, says Minister", Irish Times, October 4, 2013.

9"UK 'going it alone' may have been a deal breaker", Irish Independent, March 7, 2014.

${ }^{10}$ "Energy pact with Britain still 'inevitable' insists Rabbite”, Irish Independent, April 14, 2014.

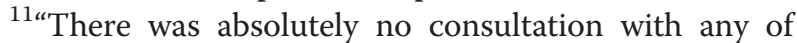
the communities", Irish Independent, April 14, 2014.

${ }^{12}$ "Events refocus minds on climate change and difficult decisions", Irish Times, April 14, 2014.

13"Race hero Ruby backs revolt over "gigantic" pylons; EirGrid accused of setting neighbour against neighbour in the rollout of (EURO) 3.2bn project", Sunday Business Post, October 27, 2013.

14"Groups revives campaign against Eirgrid power line", Irish Times, November 4, 2013.

${ }^{15}$ "Coveney denies pylon network will damage farming sector", Irish Independent, November 23, 2013.

16"Why opposition to project is so highly charged", Irish Independent, December 4, 2013.

17"Rabbitte says that pylon consultations need to improve", Irish Times, January 4, 2014.

18“Bruton says pylons crucial to regional job creation; Minsters says areas linked to a modern power network will attract investment", Irish Times, January 6, 2014.

19“"Government dimmer than a candle in a blackout if it thinks it can park pylon row", Irish Independent, January 11, 2014.

20"Review of pylon plan 'election stunt", Irish Examiner, January 29, 2014.

${ }^{21}$ "We definitely could have done things better on pylons issue admit Eirgrid chief", Irish Independent, February 17, 2014. 
22"Higher electricity bills for 50 years if cables are buried; Electricity costs would rise 3pc per year - study", Irish Independent, February 18, 2004.

23"Plan for a monster rally underlines 70pc opposition to pylon plan: poll”, Sunday Independent, March 2, 2014.

24"Ministers plan to find out why the public opposes pylons, wind farms", Irish Independent, April 4, 2014.

25 "Eirgrid announces underground options for controversial Grid West pylon project", Irish Independent, June 23, 2014.

26 "Towards a low carbon society", Irish Times, May $31,2014$.

27 "A necessary public debate on electricity power lines”, Irish Times, June 24, 2014.

\section{Competing interests}

The authors declare that they have no competing interests.

\section{Authors' contributions}

GM designed the study, synthesised the theoretical literature and collected and analysed the initial data. EB reviewed and synthesised the technical and policy literature. The paper is nevertheless a wholly collaborative venture between the participating authors. Both authors read and approved the final manuscript.

\section{Acknowledgements}

We would like to acknowledge Ann Michelle Mullally for her technical assistance with the automated referencing system. We also wish to acknowledge the support and encouragement of the journal editors and the editors of the special issue, as well as the participants in our workshop (Smart Energy System Transition in Cities and Regions) for their feedback on an earlier version of this article during the ESEIA conference held on April 24 and 25, 2014, at the University of Twente. The comments of the anonymous reviewers were critical to the revision of the original submission. Finally, we wish to acknowledge our indebtedness to ongoing conversations with Paul Bolger, Paul Deane, Niall Dunphy, Brian Ó' Gallachóir, Fionn Rogan, Colin Sage and Clare Watson, all at University College, Cork, without in any way implicating them in our conclusions.

\section{Author details}

${ }^{1}$ Energy, Climate and Community Response Group/Sustainability in Society, Department of Sociology, School of Sociology and Philosophy, University College Cork, Western Road, Cork, Republic of Ireland. 'Energy, Climate and Community Response Group/Sustainability in Society Department of Process and Chemical Engineering, School of Engineering, University College Cork, Western Road, Cork, Republic of Ireland.

\section{Received: 24 April 2015 Accepted: 15 December 2015}

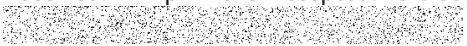

\section{References}

1. RTE News (2014) Thousands protest over wind and energy policy. http:// www.rte.ie/news/2014/0415/609006-wind-protest/. Accessed 10 Oct 2015

2. Sustainable Energy Authority of Ireland (2014) Energy in Ireland: key statistics 2014. Dublin. Available at http://www.seai.ie/Publications/Statistics_ Publications/Energy_in_Ireland/Energy_in_Ireland_Key_Statistics/EnergyinIreland-Key-Statistics-2013.pdf

3. Ballo IF (2015) Imagining energy futures: sociotechnical imaginaries of the future smart grid in Norway. Energy Res Soc Sci 9:9-20

4. Amin S (2011) Smart Grid: overview, issues and opportunities. Advances and challenges in sensing, modeling, simulation, optimization and control. Eur J Control 17:547-567. doi:10.3166/EJC.17.547

5. Skjølsvold TM, Ryghaug M, Berker T (2015) A traveler's guide to smart grids and the social sciences. Energy Res Soc Sci 9:1-8. doi:10.1016/j. erss.2015.08.017

6. Carley S, Andrews RN (2012) Creating a sustainable U.S. electricity sector: the question of scale. Policy Sci 45:97-121. doi:10.1007/s11077-012-9152-z
7. Mengolini A, Vasiljevska J (2013) The social dimension of smart grids. JRC scientific and policy report. doi:10.2790/94972

8. Blumsack S, Fernandez A (2012) Ready or not, here comes the smart grid! Energy 37:61-68. doi:10.1016/j.energy.2011.07.054

9. Laird FN (2013) Against transitions? Uncovering conflicts in changing energy systems. Sci Cult 22:149-156. doi:10.1080/09505431.2013.786992

10. Wolsink M (2012) The research agenda on the social acceptability of distributed generation in smart grids: renewable as common pool resources. Renew Sustain Energy Rev 16:822-835

11. Burch S (2011) Sustainable development paths: investigating the roots of local policy responses to climate change. Sustain Dev 19:176-188. doi:10. $1002 /$ sd.435

12. Boyle D (2013) Energy for Ireland and Europe: sustainable democratic energy for Ireland and Europe. Green Europe Foundation, Luxembourg

13. Curtin J (2012) Decarbonising energy end use. Background paper no. 6. Final report from the NESC secretariat. Irelands' climate change challenge: connecting how much with how to. National Economic and Social Council, Dublin

14. Government of Ireland (2008) Building Ireland's smart economy: a framework for sustainable economic renewal. Government of Ireland, Dublin

15. Cahill N (2012) Transforming Ireland's energy system: the role of electricity. Background paper no.5. Final report from the NESC secretariat. Irelands' climate change challenge: connecting how much with how to. National Economic and Social Council, Dublin

16. Moore J (2012) Social and behavioural aspects of climate change. Background paper no. 3. Final report from the NESC secretariat. Ireland's climate change challenge: connecting how much with how to. National Economic and Social Council, Dublin

17. Giordano V, Vasiljevska J, Vitiello S, Filiou C, Gras S, Mrdeza M (2013) Evaluation of smart grid projects within the Smart Grid Task Force Expert Group 4 (EG4), application of the assessment framework for energy infrastructure projects of common interests in the field of smart grids. Joint Research Centre of the European Commission, Luxembourg

18. Energy Needs Ireland (ENI) (2013) Cost benefit analysis for a full and immediate smart grid rollout in Ireland. Energy Needs Ireland (ENI), Dublin

19. Energy Needs Ireland (ENI) (2013) ENI 2013 consumer research survey. Energy Needs Ireland (ENI), Dublin

20. Jennings M (2013) A smarter plan? Policy comparison between Great Britain and Ireland's deployment strategies for rolling out new metering technologies. Energy Policy 57:462-468

21. Goodbody C, Walsh E, McDonnell K, Owende P (2013) Regional integration of renewable energy systems in Ireland — the role of hybrid systems for small communities. Electr Power Energy Syst 44:713-720

22. Foley A, Connolly D, Leahy P, Vad B (2010) Electrical energy storage \& smart grid technologies to integrate the next generation of renewable power systems. Sustain. Energy Environ. Prot. Aalborg Universitet, Denmark

23. Foley A, Ó' Gallachóir B, McKeogh E, Milborrow D, Leahy PG (2013) Addressing the technical and market challenges to high wind power integration in Ireland. Renew Sustain Energy Rev 19:692-703

24. Claudy M, Michelsen C, O' Driscoll A, Mullen M (2010) Consumer awareness in the adoption of microgeneration technologies: an empirical investigation in the Republic of Ireland. Renew Sustain Energy Rev 14:2154-2160

25. Rogers EM (2003) The diffusion of innovations, 5th edn. Free Press, New York

26. Li Z, Reynolds A, Boyle F (2014) Domestic integration of micro-renewable electricity generation in Ireland - the current status and economic reality. Renew Energy 64:244-254

27. Rifkin J (2011) The third industrial revolution: how lateral thinking is transforming energy, the economy, the world. Palgrave McMillian, London

28. Lennon M, Scott M (2015) Contending expertise: an interpretive approach to (re)conceiving wind power's "planning problem". J Environ Policy Plan 17:593-616. doi:10.1080/1523908X.2014.1003349

29. Shove E (1997) Revealing the invisible: sociology, energy and the environment. In: Woodgate G, Redclift MM (eds) International Handbook of Environmental Sociology, 1st edn. Edward Elgar, Cheltenham and Northampton, pp 261-273

30. Mullally G (2004) Shakespeare, the structural funds and sustainable development: reflections on the Irish experience. Innov Eur J Soc Sci Res 17:25-42

31. Byrne EP, Mullally G (2015) Engaging with sustainability through collaborative and transdisciplinary approaches to education. The 7th 
International Conference on Engineering Education for Sustainable Development. Vancouver

32. Mullally G (2012) Governance and participation for sustainable development in Ireland: not so different after all? In: Meadowcroft J, Langhelle O, Ruud A (eds) Governance, democracy sustainable development: moving beyond the impasse. Edward Elgar, Cheltenham and Northampton, pp 145-171

33. Mullally G, Henry A, Motherway B, O'Mahony J, Weyman G (2004) Sustainable participation? Evaluating the role of the city and county development boards in promoting public participation in local sustainable development. Environmental Protection Agency, Wexford

34. Mullally G, Murphy G (2008) Ireland: putting the wind up the political System? In: Lafferty W, Ruud A (eds) Promoting sustainable electricity in Europe: challenging the path-dependence of dominant energy systems. Edward Elgar, Cheltenham, pp 102-129

35. Lennon M, Scott M (2015) Opportunity or threat: dissecting tensions in a post-carbon rural transition. Sociol Ruralis n/a-n/a. doi:10.1111/soru.12106

36. Burns TR (2012) The sustainability revolution: a societal paradigm shift. Sustainability 4:1118-1134. doi:10.3390/su4061118

37. Verbong $G$, Loorbach D (2012) Introduction. In: Verbong G, Loorbach D (eds) Governing energy transitions reality: illusion or necessity. Routledge, New York and London, pp 1-23

38. Department of Communications, Energy and Natural Resources (DCENR) (2012) Government policy statement on the strategic importance of transmission and other energy infrastructure. Department of Communications, Energy and Natural Resources (DCENR), Dublin

39. Verbong GPJ, Beemsterboer S, Sengers F (2013) Smart grids or smart users? Involving users in developing a low carbon electricity economy. Energy Policy 52:117-125. doi:10.1016/j.enpol.2012.05.003

40. Minsch J, Flüeler T, Goldblatt DL, Spreng D (2012) Lessons for problemsolving energy research in the social sciences. In: Spreng D, Flüeler T, Goldblatt DL, Minsch J (eds) Tackling long-term global energy problems: the contribution of the social sciences. Springer, Netherlands, pp 273-319

41. Warren C, Cowell R, Ellis G, Strachan PA, Szarka J (2012) Wind power: towards a sustainable energy future? In: Szarka J, Cowell R, Ellis G, Strachan PA, Warren C (eds) Learning from wind power : governance and societal perspectives on sustainable energy. Palgrave Macmillan, Hampshire and New York, pp 1-14

42. Fuchs G, Hinderer N, Kungl G, Neukirch M (2012) Adaptive capacities, path creation and variants of sectoral change: the case of the transformation of the German energy supply system. SOI Discussion Paper 2012-02, University of Stuttgart, Institute for Social Sciences, Department of Organizational Sociology and Innovation, Stuttgart

43. Ault G, Frame D, Hughes N, Strachan N (2008) Electricity network scenarios for Great Britain in 2050 final report for OFGEM's LENS project. OFGEM, London

44. Van der Vleuten E, Högselius P, Hommels A, Kaijser A (2013) Europe's critical infrastructure and its vulnerabilities: promises, problems, paradoxes. In: Högselius P, Hommels A, Kaijser A, Van der Vleuten E (eds) The making of Europe's critical infrastructure: common connections and shared vulnerabilities. Palgrave Macmillan, Basingstoke and New York

45. Latour B (2011) Networks, societies, spheres: reflections of an actor-network theorist. Int J Commun 5:796-810. doi:10.1111/1468-2427.00309

46. Brown T, Budd L, Bell M, Rendell H (2011) The local impact of global climate change: reporting on landscape transformation and threatened identity in the English regional newspaper press. Public Underst Sci 20:658-673. doi:10. 1177/0963662510361416

47. Dirikx A, Gelders D (2010) To frame is to explain: a deductive frame-analysis of Dutch and French climate change coverage during the annual UN Conferences of the Parties. Public Underst Sci 19:732-742. doi:10.1177/ 0963662509352044

48. Nerlich B, Forsyth R, Clarke D (2012) Climate in the news: how differences in media discourse between the US and UK reflect national priorities. Environ Commun 6:44-63. doi:10.1080/17524032.2011.644633

49. Department of Communications Energy and Natural Resources (DCENR) (2013) Minister Rabbitte opens Ireland's first community-owned wind farm in Templederry, Co. Tipperary. http://www.merrionstreet.ie/en/News-Room/ Releases/minister-rabbitte-opens-irelands-first-community-owned-windfarmin-templederry-co-tipperary.51798.shortcut.html. Accessed 6 Apr 2014

50. McDonald C (2014) Winds of change-Templederry wind farm. http://www. irishbuildingmagazine.ie/2014/01/05/winds-of-change-templederry-windfarm/\#sthash.EV4NCfwB.dpuf. Accessed 6 Apr 2014

51. Economic N, Council S (2014) Wind energy in Ireland : building community engagement and social support. National Economic and Social Council, Dublin
52. Moore J (2012) Social and behavioural aspects of climate change. Background paper no.3. Final report from the NESC secretariat. Irelands' climate change challenge: connecting how much with how to. National Economic and Social Council, Dublin

53. Corcoran A (2012) Public acceptance of electric power system infrastructure EirGrid. C3-107 CIGRE

54. Baker S (1990) The evolution of the Irish ecology movement. In: Rüdig W (ed) Green politics one. Edinburgh University Press, Edinburgh, pp 47-81

55. EirGrid (2014) Reviewing and improving our public consultation process. EirGrid, Dublin

56. Engineers Ireland (2015) EirGrid explains grid development strategy —and wants your views. In: Eng. J. http://www.engineersjournal.ie/2015/05/05/ eirgrid-grid-development-strategy/.

57. EirGrid (2015) EirGrid welcomes conclusion of Independent Expert Panel review on Grid Link project. http://www.eirgridgroup.com/newsroom/gridlink-independent-expert-review/index.xml. Accessed 10 Oct 2015

58. Department of Communications Energy and Natural Resources (DCENR) (2015) Minister Alex White welcomes EirGrid announcement on grid link project. http://www.dcenr.gov.ie/news-and-media/en-ie/Pages/PressRelease/ Minister-Alex-White-welcomes-Eirgrid-announcement-on-Grid-Link-project. aspx. Accessed 10 Oct 2015

\section{Submit your manuscript to a SpringerOpen ${ }^{\circ}$ journal and benefit from:}

- Convenient online submission

- Rigorous peer review

- Immediate publication on acceptance

- Open access: articles freely available online

High visibility within the field

- Retaining the copyright to your article

Submit your next manuscript at $\gg$ springeropen.com 